\title{
SHORT COMMUNICATION \\ EFFECT OF DIFFERENT LEVELS OF SOLUBLE FERTILIZERS ON NUTRIENT UPTAKE IN SOLANUM MELONGENA L.
}

\section{K. MUTHUMANICKAM*, A. ANBURANI}

Department of Horticulture, Faculty of Agriculture, Annamalai University Annamalai Nagar 608 o02, Chidambaram, Tamil Nadu, India

\begin{abstract}
Field investigation was carried out to study the influence of quality parameters and nutrient uptake of brinjal hybrids due to application of various levels of water soluble fertilizer. Foliar spray of NPK (19:19:19) at 0.5 per cent and 1\% along with 100 and $75 \%$ recommended dose of NPK (200:150:100 kg ha-1) with 5 and 7 sprays, each starting from 30 DAT at $10 \mathrm{~d}$ interval, formed twenty treatments in two hybrids. Results showed that among the two different concentrations of foliar applied nutrients, 7 sprays of $1 \%$ NPK (19:19:19) along with 100 per cent recommended dose of fertilizer (200:150:100 $\mathrm{kg}^{-1}$ ) recorded the ascorbic acid content, total soluble solids (TSS) and total phenol content. Uptake of major nutrients was found to be the highest due to foliar application of 1 per cent water soluble fertilizer ( 7 sprays) along with 100 per cent recommended dose of fertilizer.
\end{abstract}

Keywords: Water soluble fertilizers, Yield parameter, Brinjal

\section{INTRODUCTION}

Brinjal (Solanum melongena L.) is also popularly called as eggplant or aubergine. The brinjal hybrids are more responsive to fertilizer application. Since, hybrids have high yield potential, it needs uninterrupted supply of nutrients both during vegetative and reproductive stage of growth [1]. Water soluble fertilizers also plays an important role in preventing the flower and fruit drop and improves crop yield and quality. [2]. Water soluble fertilizers can advantageously be utilized for foliar feeding and fertigation, thus helping in precision agriculture. Foliar spray is the modern method of fertilizer in vegetable crops due to nature of heavy feeder of nutrients [3]. An application of nutrients through foliar spray has several advantages in supplementing the nutritional requirement of crops. Hence, the present research was undertaken to estimate the effect of water soluble fertilizers on quality parameters and nutrient uptake of brinjal hybrid.

\section{MATERIALS AND METHODS}

A field experiment was carried out at University Orchard, Department of Horticulture, Faculty of Agriculture, Annamalai University, Annamalai Nagar, Tamil Nadu to study the effect of water soluble fertilizer on growth parameters of brinjal. Two brinjal hybrids viz., Mahyco No.39 (Ravaiya) produced by Mahyco Seed Innovation P. Ltd Maharashtra and Indam Supriya produced by IndoAmerican Hybrid Seeds (India) P. Ltd Bengaluru were used in the present study. The experiment was laid out in Factorial Randomized Block Design and replicated thrice. The treatments consisted of application of two levels of inorganic fertilizer (100\% and 75\% Recommended Dose Fertilizer@200:150:100 kg NPK) along with the two concentrations of water soluble fertilizers viz., NPK (19:19:19) at $0.5 \%$ and $1 \%$ as in five and seven sprays. Seeds were sown in raised beds at a spacing of $5 \mathrm{~cm}$ across the beds and at a depth of $0.25 \mathrm{~cm}$. Thirty-five days old healthy seedlings were transplanted in the main field. The seedlings were planted in a uniform spacing of $90 \mathrm{~cm} \times 60$ $\mathrm{cm}$ in the plot and immediately after transplanting. Intercultural operations and harvesting were done as per the recommendation. Th required quantity of manures and fertilizers were applied as per the treatment. The inorganic fertilizers were applied in the form of urea, superphosphate and murate of potash as per the treatments. $\mathrm{N}$ was applied in two split doses, first dose was given as a basal application and the remaining $\mathrm{N}$ was given thirty days after sowing. The full dose of phosphorus and potassium were applied as basal application at the time of transplanting. Foliar application of required quantity of 19:19:19 NPK were given in five and seven sprays starting from thirty days after transplanting at ten days intervals. The observations on various quality parameters viz., Ascorbic acid, Total soluble solids (TSS), Total phenol content and nutrient uptake were recorded and statistically analysed as given by [4].

\section{Received 29 March 2018; Accepted 20 May 2018 \\ *Corresponding Author}

\section{K. Muthumanickam}

Department of Horticulture, Faculty of Agriculture, Annamalai University Annamalai Nagar 608 o02, Chidambaram, Tamil Nadu, India

Email: muthusai121@gmail.com

( This article is open access and licensed under the terms of the Creative Commons Attribution License (http://creativecommons.org/licenses/by/4.o/) which permits unrestricted, use, distribution and reproduction in any medium, or format for any purpose, even commercially provided the work is properly cited. Attribution - You must give appropriate credit, provide a link to the license, and indicate if changes were made. 


\section{RESULTS}

The quality parameters viz., ascorbic acid and total phenol content did not show significant effect due to interaction of treatment $\mathrm{x}$ hybrids. The highest plant nutrient uptake was observed in $\mathrm{T}_{10} \mathrm{H}_{2}(100 \% \mathrm{RDF}+\mathrm{WSF} 1.0 \%+7$ Sprays in Ravaiya) with the mean value of 99.35: $33.52: 81.83 \mathrm{~kg}$ NPK ha-1.

\section{DISCUSSION}

In the present study, application of various levels of inorganic and water soluble fertilizers significantly influenced the fruit yield per plant. Among the various treatments that tested maximum TSS content was recorded in $\mathrm{T}_{10}\left(5.03 \mathrm{~B}^{\circ}\right)$ which received $100 \% \mathrm{RDF}+\mathrm{WSF}$ $1.0 \%+7$ Sprays and the minimum was recorded in $75 \%$ recommended dose of fertilizers in $\mathrm{T}_{1}\left(4.22{ }^{\circ} \mathrm{B}\right)$. The interaction effect did not show significant variation.

The TSS content constitutes the organic and inorganic substances present in cell sap. They also contribute to the osmoregulation function. The turgidity maintenance is governed by the osmoregulatory mechanism. The increased TSS content evidently shows that the stored food materials undergo either partial or complete hydrolysis and provide substrate for respiration [5].

Whole plant testing is used to measure uptake of nutrients by plants [6]. Concentrated accumulation (or dilution) of a non-metabolized ion in a growing plant is obviously due to the results of imbalance between rates of net uptake.

In the present study, application of various levels of inorganic and water soluble fertilizers significantly influenced the nutrient uptake. Among the various treatments that tested more uptake of nitrogen $(92.44 \mathrm{~kg}$ ), phosphorus (30.94 kg) and potassium $(78.67 \mathrm{~kg})$ uptake were recorded in $\mathrm{T}_{10}$ which received $100 \% \mathrm{RDF}+\mathrm{WSF} 1.0 \%+7$ Sprays and the minimum was recorded in $75 \%$ recommended dose of fertilizers in $\mathrm{T}_{1}$ $\left(63.13,11.13\right.$ and $\left.58.64 \mathrm{~kg} \mathrm{NPK} \mathrm{ha}^{-1}\right)$.

Among the hybrids tested $\mathrm{H}_{1}$ recorded the highest uptake of 83.46: 23.15: $64.61 \mathrm{~kg} \mathrm{NPK} \mathrm{ha}{ }^{-1}$ and the least was recorded in $\mathrm{H}_{2}$ (85.54: 28.36: $81.83 \mathrm{~kg} \mathrm{NPK} \mathrm{ha}^{-1}$ ) with regard to interaction effect $\mathrm{T}_{10} \mathrm{H}_{1}$ recorded the highest uptake (99.35: 33.52: $81.83 \mathrm{~kg} \mathrm{ha}^{-1}$ ) and the least was recorded in $\mathrm{T}_{1} \mathrm{H}_{2}$ (61.18: 10.20: $61.39 \mathrm{~kg} \mathrm{NPK} \mathrm{ha}^{-1}$ )

The increased uptake may be attributed to the cumulative effect of increased nutrient content and highest dry matter production. The results are in line with the findings of [7, 8] and [9]. The plant N, P and K uptake increased when the particular nutrient was applied at higher levels. The increased accumulation of NPK in the plant may be attributed to more availability of the respective nutrients and more absorptive area which resulted in the highest nutrient accumulation. Another reason might be due to steady and sustained effect of water soluble fertilizers in supplying proportionate nutrients at right time which resulted in uniform and higher growth rate throughout the crop period. These findings are in conformity with the results of [9].

\section{CONCLUSION}

Based on the present investigation, among the water soluble fertilizers and inorganic fertilizers tested foliar application of 7 sprays of NPK (19:19:19) along with the $100 \%$ application of inorganic fertilizer (200:150:100 kg NPK ha-1) recorded the highest quality parameters and nutrient uptake in brinjal.

Table 1: Effect of water soluble fertilizers on quality arameters and nutrient uptake in brinjal hybrid

\begin{tabular}{|c|c|c|c|c|c|c|}
\hline Treatments & $\begin{array}{l}\text { Days to } 50 \% \\
\text { flowering }\end{array}$ & $\begin{array}{l}\text { TSS } \\
\text { ( }{ }^{\circ} \text { Brix) }\end{array}$ & $\begin{array}{l}\text { Total phenol } \\
\text { (g) }\end{array}$ & $\begin{array}{l}\text { N uptake } \\
\left(\text { (kg hat) }^{1}\right)\end{array}$ & $\begin{array}{l}\text { P uptake } \\
\left(\mathrm{kg} \mathrm{ha}^{-1}\right)\end{array}$ & $\begin{array}{l}\text { K uptake } \\
\left(\text { kg ha-1) }^{-1}\right)\end{array}$ \\
\hline $\mathrm{F}_{1} \mathrm{H}_{1}$ & 0.46 & 3.88 & 0.10 & 65.08 & 12.06 & 61.39 \\
\hline $\mathrm{F}_{2} \mathrm{H}_{1}$ & 0.63 & 4.00 & 0.11 & 68.84 & 16.38 & 65.44 \\
\hline $\mathrm{F}_{3} \mathrm{H}_{1}$ & 0.71 & 4.04 & 0.11 & 71.81 & 18.78 & 67.05 \\
\hline $\mathrm{F}_{4} \mathrm{H}_{1}$ & 0.67 & 4.06 & 0.12 & 76.82 & 21.23 & 69.55 \\
\hline $\mathrm{F}_{5} \mathrm{H}_{1}$ & 0.75 & 4.09 & 0.13 & 84.73 & 22.28 & 73.60 \\
\hline $\mathrm{F}_{6} \mathrm{H}_{1}$ & 0.67 & 4.36 & 0.12 & 87.15 & 24.34 & 72.65 \\
\hline $\mathrm{F}_{7} \mathrm{H}_{1}$ & 0.73 & 4.39 & 0.11 & 90.2 & 26.13 & 76.15 \\
\hline $\mathrm{F}_{8} \mathrm{H}_{1}$ & 1.38 & 4.47 & 0.12 & 93.25 & $27 \cdot 38$ & 79.75 \\
\hline $\mathrm{F}_{9} \mathrm{H}_{1}$ & 1.68 & 4.51 & 0.13 & $97 \cdot 31$ & 29.44 & 77.50 \\
\hline $\mathrm{F}_{10} \mathrm{H}_{1}$ & 1.98 & 4.52 & 0.14 & 99.35 & 33.52 & 81.83 \\
\hline $\mathrm{F}_{1} \mathrm{H}_{2}$ & 1.30 & 4.57 & 0.10 & 61.18 & 10.20 & 55.88 \\
\hline $\mathrm{F}_{2} \mathrm{H}_{2}$ & 1.76 & 5.12 & 0.10 & 64.23 & 14.05 & $57 \cdot 34$ \\
\hline $\mathrm{F}_{3} \mathrm{H}_{2}$ & 1.98 & 5.24 & 0.10 & 66.28 & 16.51 & 59.41 \\
\hline $\mathrm{F}_{4} \mathrm{H}_{2}$ & 1.89 & 5.29 & 0.11 & 69.13 & 17.77 & 61.46 \\
\hline $\mathrm{F}_{5} \mathrm{H}_{2}$ & 2.10 & 5.33 & 0.12 & 71.33 & 19.82 & 63.54 \\
\hline $\mathrm{F}_{6} \mathrm{H}_{2}$ & 1.91 & 5.41 & 0.11 & 74.47 & 20.18 & 64.56 \\
\hline $\mathrm{F}_{7} \mathrm{H}_{2}$ & 2.04 & 5.45 & 0.11 & 76.42 & 22.21 & 67.54 \\
\hline $\mathrm{F}_{8} \mathrm{H}_{2}$ & 2.13 & 5.49 & 0.10 & 78.47 & 23.23 & 69.62 \\
\hline $\mathrm{F}_{9} \mathrm{H}_{2}$ & 2.19 & $5 \cdot 5^{2}$ & 0.14 & 81.49 & 25.30 & 71.19 \\
\hline $\mathrm{F}_{10} \mathrm{H}_{2}$ & 2.56 & 5.55 & 0.13 & 85.54 & 28.36 & $75 \cdot 51$ \\
\hline S. Ed & 0.05 & 0.25 & 0.08 & 1.26 & 1.07 & 1.34 \\
\hline $\mathrm{CD}(\mathrm{P}=0.05)$ & NS & NS & NS & 2.52 & 2.15 & 2.68 \\
\hline
\end{tabular}




\section{REFERENCES}

1. Ranjith kumar, S. 2009. Studies on the effect of foliar application of water soluble fertilizer on growth, yield and quality of brinjal (solanum melongena l.) hybrids. Thesis, PAJNCAO, Karaikal.

2. Sendhil Valavan. P and K. R Kumaresan. 2006. Relative efficiency of controlled release and water soluble fertilizers on the yield and quality of tomato (Lycopersicon esculentum Mill.). J. Agron., 5:519-522.

3. Vibhute, C. P. 1998. A process for manufacturing complex solid and liquid completely water soluble fertilizers. Fert. News., 43: 63.

4. Panse, V. C. and P. V. Sukhatum. 1978. Statistical methods for agricultural workers.

5. Tamilselvi, P., R. M. Vijayakumar and P. Nainar. 2004. Studies on the effect of foliar application of micronutrients on quality of tomato (Lycopersicon esculentum Mill.) cv PKM-1. South Indian Hort., 53(16): $272-275$.

6. Le Bot, J., S. Adamowicz and P. Robin. 1998. Modelling plant nutrition of horticulture crops. Scientia Hort., 74:477-482.

7. Subbiah, B. V. and G. L. Asija. 1976. Available rapid produce for estimation of available nitrogen in soil. Curr. Sci., 81: 277-279.

8. Yadav, B. D., R. B. Khandelwal and Y. K. Sharma. 2004. Response of tomato to foliar feeding of water soluble fertilizers. Veg. Sci., 31: 98-100.

9. Manjunatha, G. 2004. Effect foliar nutrition of water soluble fertilizers in bhendi (Abelmoschus esculentus) hybrid. M. Sc. (Hort.) thesis, Tamil Nadu Agricultural University, Coimbatore. 